\title{
The Role of Corporate Social Responsibility in Seeking to Create a Position for a Brand
}

\author{
Hojjat Taheri Goodarzi $(1)$, Nooroddin Gohari (2) \\ 1. Department Of Public Management, Borujerd Branch, Islamic Azad University,Borujerd,Iran \\ (Corresponding Author) \\ 2.Master Of Public Management, Borujerd Branch, Islamic Azad University,Borujerd, Iran
}

\begin{abstract}
The objective of the present research is to study the relationship between accepting corporate social responsibility and seeking to create a position for the corporate's brand. To do this, the role of corporate social responsibility acceptance on the basis of Carroll's 4-dimensional model (other responsibility, ethical, legal, and economic dimension) on seeking to create a position on the basis of Keller's theory in the three dimensions of the power, desirability, and being unique of the environmental dependencies) were studied in two populations of Melli Bank as a governmental bank and Mellat Bank as a private bank in Lorestan Province area. On this basis, the role of the perceived proportional variables between the brand and the purpose of the company and also the perceived authenticity from the corporate's claim which was mentioned in the existence statement of the company with its observed conditions by the clients as moderator variable on the two independent and dependent variables of the research was also studied. The research method of the present research was a descriptive - correlational one. In order to gather data, three questionnaires were used one for evaluating the special value of the brand on the basis of Keller's model on the basis of the mental image of the brand and its special value for the client's viewpoint, the second questionnaire was to evaluate the predictive variables which the researcher made himself/ herself and the other questionnaire was Galbreath (2010) about the social responsibility of the corporate which the validity was calculated through content validity on the basis of the scholars and its reliability was calculated through Chronbach alpha by the SPSS software. The research sample included 392 individuals who answered the questions and were amongst the clients of both of the banks in the province's area through random stratified sampling questionnaires were provided in accordance with and were distributed among branches in the area of the province. The obtained results from the structural average in this research through the regression statistical tests in relation to comparing the two banks indicated that there is no significant relationship between corporate social responsibility and the aspects of the special value of the brand on the basis of the client (the power of environmental dependencies, the desirable environmental dependencies). While there is no significant relationship between the uniqueness of environmental dependencies of the special value of the brand on the basis of the client and corporate social responsibility in Melli Bank from the viewpoint of the clients but the results indicate the significant effect of this study on the understanding of the clients of Mellat Bank.Also the results of the regression test proved the lack of significant impact of the role of proportional moderators and also the perceived authenticity between the brand and the purpose of the company on the improvement of the special value of the brand and the corporate social responsibility taking from the viewpoint of the clients of Melli and Mellat banks. This relationship is only a proof of the role of the perceived proportional moderator and also about the power variable it proves the role of authenticity moderator on the relationship between these two variables from the viewpoint of the clients of Mellat bank as a private bank regarding the uniqueness variable.
\end{abstract}

Keywords: Corporate social responsibility, Corporate's brand,

\section{Introduction:}

The idea of making brands as a healthy way for companies to invest has been established for years. The marketing researchers use the special value of the brand as a criterion to improve approaches in order to study making a powerful brand (Lajevardi, 2012, 3).

It is imagined that the factors which can make these criteria or can affect them include a new group of brandmaking factors which are stemmed from the current of the corporate social responsibility to the society in which they are operating especially from the viewpoint of the clients which are using the presented services of these companies.

Since organizations and companies have a great influence on the social system their operations must be in a way which maximizes the positive effects of their activities and minimizes the negative influences which are the result of their activities and as the most influential member of the society, they must be concerned with the long-term essentials and desires of the society and aim at resolving the problems. 
Polonsky and Jevons (2006) believe that the companies which have perceived the way to utilize corporate social responsibility in their brand's operations have surely gained noticeable benefits in comparison to their rivals (Lajevardi, 2012, 3).

From this standpoint in the present research we aim at studying the role of corporate social responsibility on seeking to create a position for the special value of the brand.

\section{Statement of the problem:}

The role of unobservable assets on the effectiveness of the operations of the organization and also creating and the sustainability of the financial functions of the career in the area of various industries is clear to everyone. Today's world is the presence field of the successful brands which in addition to being dominant on the market's share, reinforce the trust and loyalty of the clients, they also advance the name of their country and their nation through introducing ideas and innovations in the field of international industries and trade. Understanding this role reinforces the need for the organizations and governments to create value through brands.

The marketing field activists express that the main source of creating value for a brand (for the organization as well as for the client) does not lie within product of services but in fact and potentially in the mind of the clients. Therefor concentrating on a place other than the clients' minds in order to improve the condition of the brand is a wrong affair. Of course it is clear that controlling the clients' mentality directly is an impossible affair.

The results of Allahyari and colleagues (2008) in a research article titled "improving the special value of the brand on the basis of the client through creating an image of functional and nonfunctional benefits, along studying the causal relationship between the images of functional and nonfunctional benefits resulting from the interactions of the activities for creating the brand through understanding the brand (as a case study in Mellat Bank)" indicated that the image of functional benefits had a causal relationship and a relatively strong positive correlation with knowing the brand and is considered as the cause of the shaped mentalities in relation with the brand. Therefore interaction of activities of creating a brand would be very much effective on improving the special value of the brand along creating a mentality from presenting functional benefits through the brand of a bank (Allahyari \& colleagues, 2008, 32).

Therefore two areas are clear here. One is how a brand gains value in the mind of a client and the other is creating one such value in minds. Therefore the recourses of the special value of the brand must be determined and must organize all its activities including marketing, affecting the organizational culture, providing human recourses and etc. in a way that these assets will be shaped in the minds of the clients.

The necessity to penetrate into the minds is also visible in banking industry. This point reached its peak in Iran's banking industry after the private banks entered the field of banking industry. Today we can see that private banks (the banks which were private from the very moment they started their activities) took advantage of the lack of mentality and brand in the other banks and increased their market shares quickly.

This important matter is there while in the era when economic agencies become larger and larger every day and increase in number, their effect on the social system and structure increase as well accordingly. In other words, economic agencies and companies within a social system and structure act as social subsystem and in a vast landscape they display a sort of mutual dependency on each other.

Since organizations and companies have a great impact on the social system, their activities must be carried out in a way that maximizes the positive effects resulting from its activities and minimizes the negative effects resulting from its activities and as the most influential member of the society, make an effort to gain the interest of the general mentalities, be concerned with the long- term needs and desires of the clients and try and resolve its problems.

The topic of social responsibility includes commercial behaviors and measures in the areas of labor, consumers, ecosystem supports and human rights, obedience, ethics and manner regulations, social activities, corporation welfare. Therefore nowadays attention to the topic of corporate social responsibility (CSR), which is generally the sum of activities which organizations carry out as an influential and beneficial member in the society as corporate environmental relationships, increases daily.

Therefore taking into account the increasing attention on the important topic of social accountability and also the importance of and the position of creating brands in the clients' minds, studying the relationship between corporate social accountability with seeking to create a position for the special value of the brand in the minds of the clients of the company is of special importance in the competitive environment of the market.

Poolthang \& Mandhachitara carried out a research in( 2009) titled the expectations of the client of corporate social responsibility and the perceived quality of and its effects on the brand in banking industry. The findings of this research indicated that corporate social responsibility indirectly affects variables such as satisfaction and the popularity image. Some of the positive consequences of the relationship between corporate social 
responsibility and the effect of brand could be named as follows: the commitment of the employees, market share, the image of the brand and the loyalty of the client.

Therefore on the basis of the importance of the mentioned discussions, this research was dedicated to studying the role of corporate social accountability on creating the special value of a brand with emphasis on the mental image of the brand through the indexes of power, desirability and uniqueness using evaluating corporate social responsibility (CSR) through the 4 indexes presented by "Carroll" including the indexes of economic, legal, ethical and the innate abilities and capabilities of the organization. Among all these the role of elements such as the perceived coordination between the brand and the purpose of the company and also the perceived authenticity from the company's claim regarding the company's brand are the moderator elements of studying the role of corporate social accountability on creating the brand's special value from the viewpoint of the clients of Melli Bank (as a governmental bank) and Mellat Bank (as a private bank) as a comparative study is attended to. On this basis the main question of the research is:Can corporate social accountability be effective in seeking to create a position for the special value of the brand from the viewpoint of the clients?

\section{Research Hypotheses}

The main hypothesis: it seems like there is relationship between corporate social accountability and seeking to create a position for the special value of brand from the viewpoint of the clients.

H1: there is significant relationship between corporate social accountability and increasing the power of environmental dependencies of the special value of the brand from the viewpoint of the clients.

$\mathrm{H} 2$ : there is a relationship between corporate social accountability and increasing the desirability of environmental dependencies of the social value of the brand from the viewpoint of the client.

H3: there is a relationship between corporate social accountability and increasing the uniqueness of the environmental dependencies of the special value of the brand from the viewpoint of the clients.

H4: it seems like the perceived coordination between the brand and the purpose of the company moderates the relationship between corporate social accountability and the improvement of the special value of the brand in the viewpoint of the clients.

H5: it seems like the perceived coordination between the brand and the purpose of the company moderates the relationship between corporate social accountability and the increasing the power of environmental dependencies of the special value of the brand in the viewpoint of the clients.

H6: it seems like the perceived authenticity from the claim of the company (the existence statement of the company) moderates the relationship between corporate social accountability and the special value of the brand from the viewpoint of the clients.

H7: it seems like the perceived authenticity from the claim of the company (the existence statement of the company) moderates the relationship between corporate social accountability and the increasing power of environmental dependencies of the special value of the brand from the viewpoint of the clients.

\section{The theoretical frame and conceptual model of the research}

We aim at answering the question that "can corporate social accountability be effective on seeking to create a position for special value of the brand from the viewpoint of the clients?" in this research.

On the basis of the carried out researches, the recourse and the main root of the special value of a brand on the basis of the client is the mentalities shaped by the brand. These shaped mentalities manifest as knowing the brand (Aaker, 1992, 29).

According to Keller's (1993) theory, in this research, the knowledge of brand will be evaluated as the attention the brand receives and the image of the brand. According to Keller's theory of the special value of a brand on the basis of the client, it is dependent on the desirability and power and uniqueness of the environmental dependencies related to the company's brand (Benoit Moreau \& Pargol, 2011, 104).

On this basis the dependent variables of the present research include:

- The power of the environmental dependencies of the special value of the brand

- The desirability of the environmental dependencies of the special value of the brand

- The uniqueness of the environmental dependencies of the special value of the brand

On the other hand taking into account the question of the research, in order to evaluate the corporate social responsibility variable, Carroll's 4- dimensional model of corporate social responsibility was used:

- Corporate economic responsibility

- Corporate legal responsibility

- Corporate ethical responsibility

- Corporate precautionary responsibility

And the moderator variables are:

- The perceived proportion between the brand and the purpose of the company

- The perceived authenticity from the company's claim in its existence statement 
The conceptual definition of the technical expressions and terms of the variables of the research are as explained below:

The special value of the brand of the company: the Marketing Science Institute defines the brand's special value as follows:

A set of associations and behaviors on the part of the clients of the brand, the members of the channel and the parent company which enables the brand to have more income or to have a more side- benefit than the time it did not have a brand and this gives the brand a strong, stable and distinguishing benefit to the brand when competing with rivals (Gordon, 2002).

- Carroll's special value of the brand based on the client: according to Carroll (2002) studies, the recourses of value of the brand come out of being knowledgeable regarding the brand which could be determined on the basis of two elements of consciousness and the relationships of the brand.

- Being highly conscious regarding the brand and a set of the relationships of a unique, powerful and suitable brand in the memory of the consumer results in the branch having a high value.

- Mental image of the brand: the image of the brand is defined as concepts about the brand which are related to the associations in the memory of the consumer. The links of the brand are informational nodes which have been linked to the nodes related to the brand in the mind of the client and contain a concept of the brand for the client. The image of the brand has a strong influence on the behavior of the clients towards the brand (Janonis \& colleagues ,2007).

- The power of the brand: Krosno, Freiling and Skinner (2009) define the power of the brand as the capacity of the brand to influence the perceptions and values or the behaviors of the clients (Ghalandari, 2009, 33).

Also Motameni\&Shahrokhi (1998) consider a brand being powerful when it is capable of influencing the behavior of the consumers who are looking at it and can make the preference, tendencies, and purchasing behaviors for that brand repetitive and day to day in a normal way (Ghalandari, 2009, 28).

- The desirability of the brand: the perception of the client from the idea of becoming satisfied through consuming the goods and services of a particular brand and to enjoy its benefits.

- The uniqueness of the brand: they define the uniqueness of a brand as presenting distinguished goods and services to the clients in a way that the clients perceive that these goods and services are different from those of other companies which provide these types of services (website number 3 ).

- The perceived coordination between the brand and the purpose: Hoeffler and Keller define the perceived coordination as the perception of the client from the brand and the purpose which the brand supports. (Benoit Moreau \& Pargol 2011, 107).

- The perceived authenticity from the claim of the company: the perception the clients the clients gain from the expressed claimed regarding the goods and services presented by the company (in the fields such as: quality, stock, the manner in which they are produced and presented,...).

"lack of perceived authenticity by the clients from the company's claim in the mentioned fields can prevent the creation of a strong dependency between the clients and the company" (Benoit Moreau \& Pargol, 2011, 106).

- Corporate social responsibility: Archie Carroll (1979), has vastly defined corporate social responsibility (CSR):"business social responsibility includes the society's optional, ethical, legal and economic expectations of the organization in a specific time" (Crain and colleagues, 2009, 10).

- Corporate economic responsibility: providing jobs and creating products which the clients need to use.

- Corporate legal responsibility: adapting to the current international laws and states and local conditions.

- Corporate ethical responsibility: fulfilling the society's expectations which are not written down as laws avoiding social losses, being committed to ethical principles and rights, executing what is right and fair and ...

- Corporate precautionary responsibility: which includes other responsibilities of the company such as voluntary responsibilities in order to get results out of the activities and behaviors which are desirable fir the social institutes, cooperating in distribution of recourses for various cultural or social conditions in relation with the institutes, providing opportunity in order to use the employees and ... (Galbreath, 2010, 413). 


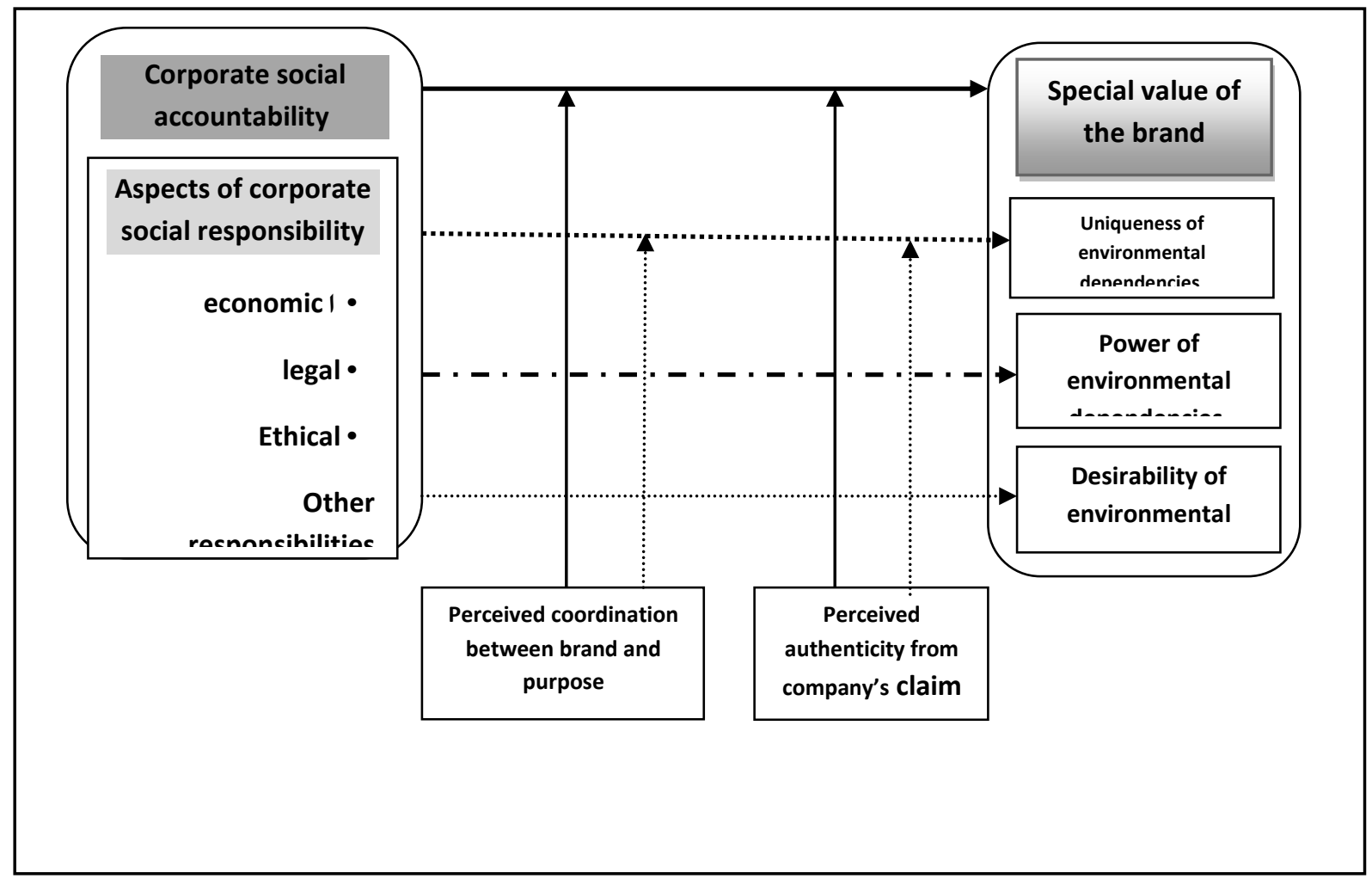

Figure (1): the conceptual model of the research

\section{Research Methodology:}

The present research is a descriptive correlational one regarding applicable purposes and from the standpoint of collecting data. Taking into account the type of the research and the type of variables for exploratory factor analysis and approving the analyses of the data correlation, regression, variance analyses and structural equations tests were used.The necessary analyses of the data were carried out using Excel spread sheet, AMOS, Lisrel and spss software.

\section{The population, sample, and the sample selection method}

Banks and financial institutes which are a part investment companies comprise the population of the present study on the basis of the topic of the research. The clients of Melli and Mellat Banks in Lorestan Province area were considered as the population under research on this basis. Selecting these two populations was to study the background of the research in Lorestan province's Melli Bank as a "governmental bank" (website number 4) and Mellat Bank as a private bank which according to Banker International Magazine had the made the most profit in the year 2012. In order to estimate the sample size in this research we used Morgan's table for determining the sample size for the infinite populations, 392 individuals were determined from each of the understudy banks as samples.

In order to distribute the instruments for collecting data from amongst the clients of the branches of Melli and Mellat Banks in 9 townships in Lorestan province, taking into account the size of the selected sample, "relative sampling stratified selection method was used in this method the population will first be divided into layers and then the number of the individuals of the sample are selected with the same proportion from the classes in the population" (Khaki, 2007, 367).

$\mathrm{N}$ : the population size

$\mathrm{N}_{\mathrm{K}}$ : the number of individuals in each group

$\mathrm{P}_{\mathrm{k}}=\frac{\mathrm{N}_{\mathrm{k}}}{\mathrm{N}} \times 100$ the ratio of the individuals in each group of the population

$\mathrm{NK}=\mathrm{P}_{\mathrm{k} \times \mathrm{n}}$ the number of individuals of the sample in each group

Recourse: (Azar and Momeni, 2008, 7)

\section{Instrumentation}

In order to collect data in this research field and library methods were used. The instruments used to collect data are two separate questionnaires. To do this, the existing questionnaires in the field of the variables of the research (Jeremy Galbreath(2010) about corporate social responsibility on the basis of Keller's model 
with a total of 22 questions. The Carroll's 4-dimensional model questionnaire is based on mental images of the brand and its special value with three dimensions of power, desirability and uniqueness of each accompanied by 4 questions, and a part is a questionnaire developed by the researcher in order to evaluate the perception of the coordination between the brand and the company's purpose through posing 2 questions and evaluating the perceived authenticity claimed by the company (existence statement of the company) through posing 3 questions. In the present research's questionnaire a total of 43 questions were used of which 4 were related to demographic information of the clients and 39 were to test the hypotheses. In order to analyze the questionnaire, the 5- option Likert scale was used.

\section{Research Findings:}

Testing the hypotheses

The Studying the relationship between the corporate social responsibility and the aspects of special value of the brand on the basis of the client of celler.In order to study the hypotheses of the research first the variables of the research must be made and then a general model must be executed in AMOS software and on the basis of the level of significance decide on the existing relationships between the variables. Power, Coordination, Desirability, Authenticity, Accountability, Uniqueness

Table (1) the results of Melli Bank's variables

\begin{tabular}{|c|c|c|c|c|c|c|}
\hline & & & & From & & \\
\hline & & & & Responsibility & Authenticity & Coordination \\
\hline & & Direct effect & Effect level & 0.007 & 0.000 & 0.000 \\
\hline & Authenticity & & $\begin{array}{c}\text { Level of } \\
\text { significance }\end{array}$ & 0.829 & $\ldots$ & $\ldots$ \\
\hline & & Indirect & Effect level & 0.000 & 0.000 & 0.000 \\
\hline & & & $\begin{array}{c}\text { Level of } \\
\text { significance }\end{array}$ & $\cdots$ & $\cdots$ & $\cdots$ \\
\hline & & Total & Effect level & 0.007 & 0.000 & 0.000 \\
\hline & & & $\begin{array}{c}\text { Level of } \\
\text { significance }\end{array}$ & 0.829 & $\ldots$ & $\ldots$ \\
\hline & & Direct effect & Effect level & 0.048 & 0.000 & 0.000 \\
\hline & & & $\begin{array}{c}\text { Level of } \\
\text { significance }\end{array}$ & 0.433 & $\cdots$ & $\cdots$ \\
\hline To & coordination & Indirect & Effect level & 0.000 & 0.000 & 0.000 \\
\hline & & & $\begin{array}{c}\text { Level of } \\
\text { significance }\end{array}$ & $\ldots$ & $\ldots$ & $\ldots$ \\
\hline & & Total & Effect level & 0.048 & 0.000 & 0.000 \\
\hline & & & $\begin{array}{c}\text { Level of } \\
\text { significance }\end{array}$ & 0.433 & $\ldots$ & $\ldots$ \\
\hline & & Direct effect & Effect level & 0.025 & -0.054 & -0.022 \\
\hline & & & $\begin{array}{c}\text { Level of } \\
\text { significance }\end{array}$ & 0.602 & 0.268 & 0.597 \\
\hline & Uniqueness & Indirect & Effect level & -0.001 & 0.000 & 0.000 \\
\hline & & & $\begin{array}{c}\text { Level of } \\
\text { significance }\end{array}$ & 0.708 & $\ldots$ & $\ldots$ \\
\hline & & Total & Effect level & 0.024 & -0.054 & -0.022 \\
\hline & & & $\begin{array}{c}\text { Level of } \\
\text { significance }\end{array}$ & 0.638 & 0.268 & 0.597 \\
\hline & & Direct effect & Effect level & 0.037 & -0.077 & 0.044 \\
\hline & Power & & $\begin{array}{c}\text { Level of } \\
\text { significance }\end{array}$ & 0.530 & 0.157 & 0.379 \\
\hline & & Indirect & Effect level & 0.002 & 0.000 & 0.000 \\
\hline & & & $\begin{array}{c}\text { Level of } \\
\text { significance }\end{array}$ & 0.517 & $\ldots$ & $\ldots$ \\
\hline & & Total & Effect level & 0.038 & -0.077 & 0.044 \\
\hline & & & $\begin{array}{c}\text { Level of } \\
\text { significance }\end{array}$ & 0.527 & 0.157 & 0.379 \\
\hline & & Direct effect & Effect level & 0.039 & 0.109 & -0.015 \\
\hline & & & $\begin{array}{c}\text { Level of } \\
\text { significance }\end{array}$ & 0.467 & 0.089 & 0.730 \\
\hline & Desirability & Indirect & Effect level & 0.000 & 0.000 & 0.000 \\
\hline & & & $\begin{array}{c}\text { Level of } \\
\text { significance }\end{array}$ & 0.995 & $\ldots$ & $\ldots$ \\
\hline & & Total & Effect level & 0.039 & 0.109 & -0.015 \\
\hline & & & $\begin{array}{c}\text { Level of } \\
\text { significance }\end{array}$ & 0.438 & 0.089 & 0.730 \\
\hline
\end{tabular}


Table (2) the results of Mellat Bank's variables

\begin{tabular}{|c|c|c|c|c|c|c|}
\hline & & & & From & & \\
\hline & & & & Responsibility & Authenticity & Coordination \\
\hline \multirow{30}{*}{ To } & \multirow{6}{*}{ Authenticity } & \multirow[t]{2}{*}{ Direct effect } & Effect level & -0.106 & 0.000 & 0.000 \\
\hline & & & $\begin{array}{c}\text { Level of } \\
\text { significance }\end{array}$ & 0.024 & $\ldots$ & $\cdots$ \\
\hline & & \multirow[t]{2}{*}{ Indirect } & Effect level & 0.000 & 0.000 & 0.000 \\
\hline & & & $\begin{array}{c}\text { Level of } \\
\text { significance }\end{array}$ & $\cdots$ & $\cdots$ & $\cdots$ \\
\hline & & \multirow[t]{2}{*}{ Total } & Effect level & -0.106 & 0.000 & 0.000 \\
\hline & & & $\begin{array}{c}\text { Level of } \\
\text { significance }\end{array}$ & 0.024 & $\ldots$ & $\ldots$ \\
\hline & \multirow{6}{*}{ coordination } & \multirow[t]{2}{*}{ Direct effect } & Effect level & 0.164 & 0.000 & 0.000 \\
\hline & & & $\begin{array}{c}\text { Level of } \\
\text { significance }\end{array}$ & 0.013 & $\cdots$ & $\cdots$ \\
\hline & & \multirow[t]{2}{*}{ Indirect } & Effect level & 0.000 & 0.000 & 0.000 \\
\hline & & & $\begin{array}{c}\text { Level of } \\
\text { significance }\end{array}$ & $\cdots$ & $\cdots$ & $\cdots$ \\
\hline & & \multirow[t]{2}{*}{ Total } & Effect level & 0.164 & 0.000 & 0.000 \\
\hline & & & $\begin{array}{c}\text { Level of } \\
\text { significance }\end{array}$ & 0.013 & $\ldots$ & $\cdots$ \\
\hline & \multirow{6}{*}{ Uniqueness } & \multirow[t]{2}{*}{ Direct effect } & Effect level & 0.003 & -0.037 & -0.094 \\
\hline & & & $\begin{array}{c}\text { Level of } \\
\text { significance }\end{array}$ & 0.923 & 0.448 & 0.079 \\
\hline & & \multirow[t]{2}{*}{ Indirect } & Effect level & -0.011 & 0.000 & 0.000 \\
\hline & & & $\begin{array}{c}\text { Level of } \\
\text { significance }\end{array}$ & 0.268 & $\ldots$ & $\cdots$ \\
\hline & & \multirow[t]{2}{*}{ Total } & Effect level & -0.008 & -0.037 & -0.094 \\
\hline & & & $\begin{array}{c}\text { Level of } \\
\text { significance }\end{array}$ & 0.912 & 0.448 & 0.079 \\
\hline & \multirow{6}{*}{ Power } & \multirow[t]{2}{*}{ Direct effect } & Effect level & 0.148 & -0.166 & 0.052 \\
\hline & & & $\begin{array}{c}\text { Level of } \\
\text { significance }\end{array}$ & 0.013 & 0.012 & 0.268 \\
\hline & & \multirow[t]{2}{*}{ Indirect } & Effect level & 0.026 & 0.000 & 0.000 \\
\hline & & & $\begin{array}{c}\text { Level of } \\
\text { significance }\end{array}$ & 0.030 & $\cdots$ & $\ldots$ \\
\hline & & \multirow[t]{2}{*}{ Total } & Effect level & 0.174 & -0.166 & 0.052 \\
\hline & & & $\begin{array}{c}\text { Level of } \\
\text { significance }\end{array}$ & 0.015 & 0.012 & 0.268 \\
\hline & \multirow{6}{*}{ Desirability } & \multirow[t]{2}{*}{ Direct effect } & Effect level & -0.043 & 0.017 & 0.011 \\
\hline & & & $\begin{array}{c}\text { Level of } \\
\text { significance }\end{array}$ & 0.484 & 0.832 & 0.947 \\
\hline & & \multirow[t]{2}{*}{ Indirect } & Effect level & 0.000 & 0.000 & 0.000 \\
\hline & & & $\begin{array}{c}\text { Level of } \\
\text { significance }\end{array}$ & 0.898 & $\ldots$ & $\ldots$ \\
\hline & & \multirow[t]{2}{*}{ Total } & Effect level & -0.043 & 0.017 & 0.011 \\
\hline & & & $\begin{array}{c}\text { Level of } \\
\text { significance }\end{array}$ & 0.947 & 0.832 & 0.513 \\
\hline
\end{tabular}

Studying the first hypothesis: as it could be seen on the basis of Figure (2) for Melli Bank's (as a governmental bank) clients corporate social accountability and the increase in environmental dependencies power of the brand of the company from the viewpoint of the clients is by 0.038 effective with the level of significance 0.527 which is bigger than 0.05 and indicates that corporate social accountability has no significant effect on the increase in the power of environmental dependencies of the brand of the company from the viewpoint of the clients.

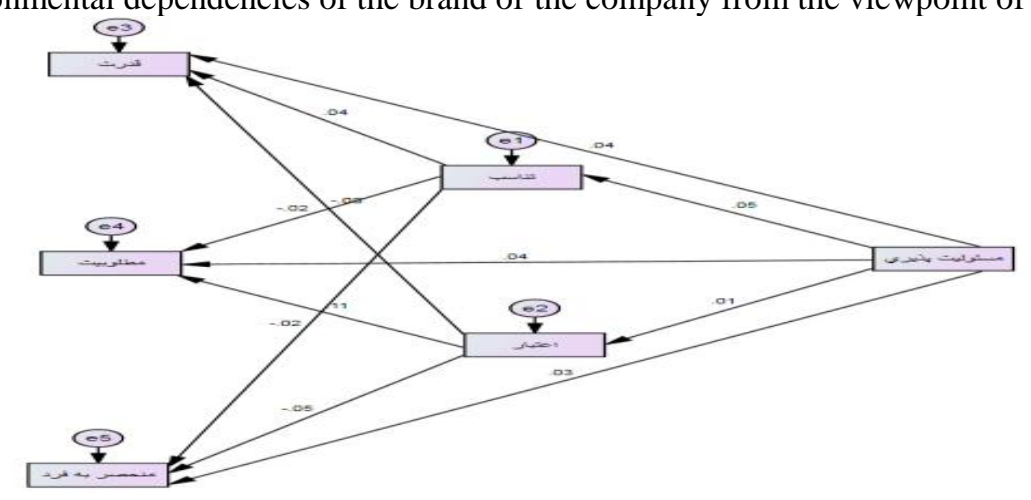


According to the information on Figure (3) in the viewpoint of the clients of Mellat Bank (as a private bank) this effect is equal to 0.174 on 0.015 level of significance which is smaller than 0.05 and indicates that corporate social accountability has a significant effect on the increase in the power of environmental dependencies of the company's brand from the viewpoint of the clients of this bank.

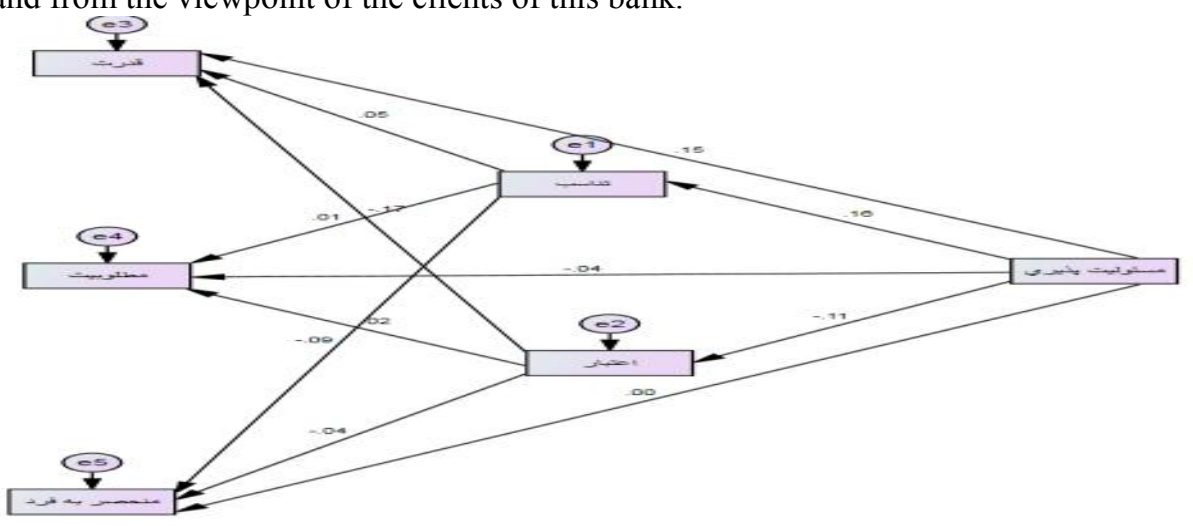

Studying the second secondary hypothesis: on the basis of the information on table (1) from the viewpoint of the clients of Melli Bank (as a governmental bank) corporate social accountability has an effect on the increase in desirability of environmental dependencies of the special value of the brand of the company from the viewpoint of the clients by 0.039 in 0.438 level of significance which is more than 0.05 and indicates that corporate social responsibility has no significant impact on the increase in the desirability of the environmental dependencies of the special value of the brand of the company from the viewpoint of the clients of this bank.

And for the clients of Mellat Bank (as a private bank) on the basis of table (2) this effect is as much as -0.043 on 0.513 level of significance which is more than 0.05 which indicates that corporate social accountability has no significant impact on the increase in the desirability of the environmental dependencies of the special value of the brand of the company from the viewpoint of the clients of this bank.

Studying the third secondary hypothesis: on the basis of table (1) for the clients of Melli Bank (as a governmental bank) corporate social accountability has no significant effect on the increase of uniqueness of environmental dependencies of the special value of the brand of the company from the viewpoint of the clients because the level of significance is 0638 which is more than 0.05 and unacceptable.

And on the basis of the information on table (2), for Mellat Bank's (as a private bank) clients corporate social accountability has no significant impact on the increase in the uniqueness of environmental dependencies of the special value of the company's brand from the viewpoint of the clients of this bank because the level of significance was not acceptable (a level of significance equal to 0.912 which is more than 0.05 ).

Studying the relationship between the moderator variables (the perceived coordination between the brand and the purpose of the company and also the perceived authenticity from the company's claim) and improving the special value of the brand from the viewpoint of the clients and also increase in the power of environmental dependencies of the special value of the brand.

Studying the fourth secondary hypothesis: taking into account figure (4) and the results of the indirect coefficients test for the clients of Melli Bank indicated that the coordination in all three issues had a level of significance not smaller than 0.05 and we can conclude that the perceived coordination between the brand and the purpose of the company does not moderate the relationship between the corporate social accountability and the improvement of the special value of the brand from the viewpoint of the clients.

Also considering figure (5) and the results from the indirect coefficients test, the coordination in all three cases has a level of significance not smaller than 0.05 and we can conclude that the perceived coordination between the brand and the purpose of the company does not moderate the relationship between corporate social accountability and the improvement of the social value of the brand from the viewpoint of Mellat Bank's clients. It is only the uniqueness issue which has a level of significance which is less than 0.05 and this, results in the fact that the perceived coordination between the brand and the purpose of the company moderates the relationship between corporate social accountability and the uniqueness from the viewpoint of the clients of the bank.

Studying the fifth secondary hypothesis: the results of figure (4) and the indirect coefficients test for the clients of Melli Bank indicated that taking into account the effect of 0.002 and the level of significance which is not smaller than 0.368 , the perceived coordination between the brand and the purpose of the company does not moderate the relationship between the corporate social accountability and the increase in the power of environmental dependencies of the brand from the viewpoint of the clients.

Studying this hypothesis regarding the clients of Mellat Bank taking into account figure (5)and the results of indirect coefficients test (the effect of 0.011 and the level of significance which is not smaller than 0.178) indicated that the perceived coordination between the brand and the purpose of the company does not moderate 
the relationship between the corporate social accountability and increase in the power of environmental dependencies of the brand from the viewpoint of the clients.

Studying the sixth secondary hypothesis: figure (4) and the results of indirect coefficients test indicate that authenticity has a level of significance not smaller than 0.05 in both cases, as a result the perceived authenticity between the brand and the purpose of the company does not moderate the relationship between the corporate social responsibility and the improvement of the special value of the brand from the viewpoint of the clients.

Studying this hypothesis regarding the clients of Mellat Bank taking into account figure (5)and the results of indirect coefficient tests indicated that the authenticity in both cases had a level of significance not smaller than 0.05 and the result of the perceived authenticity between the brand and the purpose of the company does not moderate the relationship between the corporate social accountability and the improvement of the special value of the brand from the viewpoint if the clients it is only in power's case that the level of significance is smaller than 0.05 and results in the fact that the perceived authenticity between the brand and the purpose of the company moderates the relationship between the corporate social accountability and the power from the viewpoint of the clients.

Studying the seventh secondary hypothesis: taking into account figure (4)and the results from the indirect coefficients test (the amount of the effect equals -0.001 and the level of significance is equal to 0.744 which is bigger than 0.05) as a result the perceived authenticity between the brand and the purpose of the company does not moderate the relationship between corporate social accountability and the increase in power of environmental dependencies of the brand from the viewpoint if the clients.

Studying this hypothesis regarding the clients of Mellat Bank taking into account also figure (5)and the results from indirect coefficients test indicates that authenticity in the case of increase power of the environmental dependencies of the special value of the brand has an effect of 0.018 and a level of significance equal to 0.012 which is smaller than 0.005 and as a result the perceived authenticity between the brand and the purpose of the company moderates the relationship between the corporate social accountability and the increase in the power of environmental dependencies of the brand from the viewpoint of the clients. Power /Desirability /Coordination /Accountability/ Uniqueness

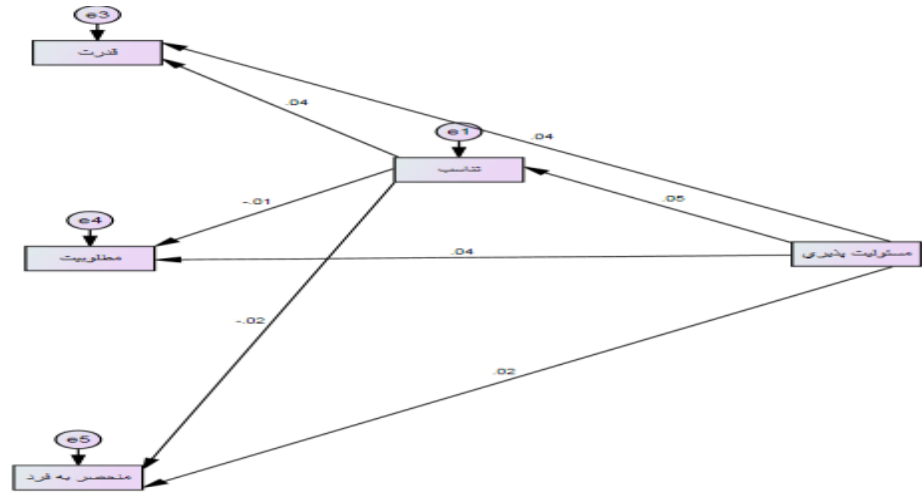

Figure 4- structural equations model for the moderator variable of the perceived coordination between the brand and the purpose in Melli Bank as a governmental bank

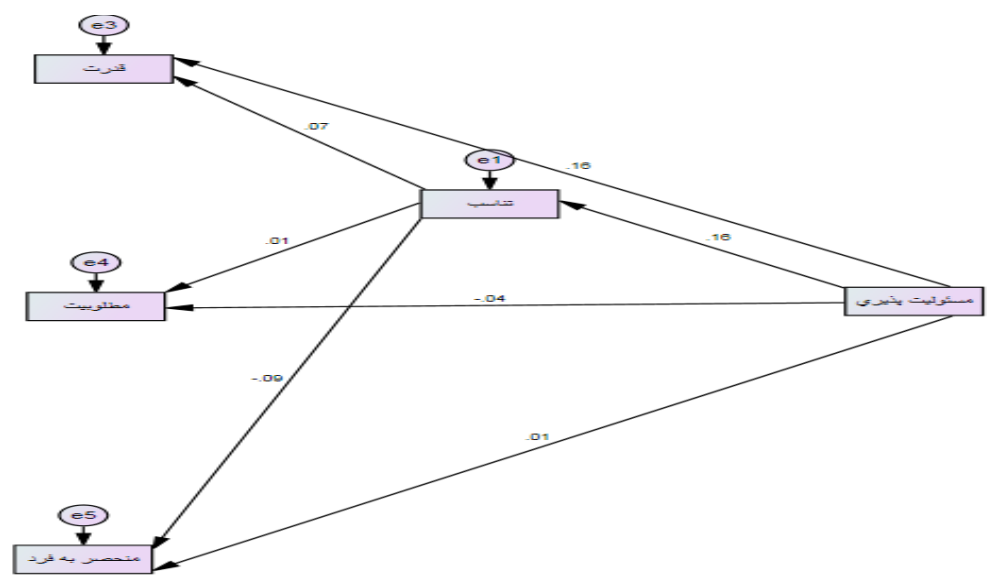

Figure 5- structural equations model for the moderator variable of the perceived coordination between the brand and the purpose in Mellat Bank as a private bank 


\section{Discussion and conclusion}

- the results of this research in the aspect of the relationship between the corporate social responsibility and the power of dependencies, considering the non- significance of this relationship from the viewpoint of the clients of Melli Bank and it being significant from the viewpoint of the clients of Mellat Bank, were in line with Kaur \& Agrawal's (2011) research results in one aspect which introduced the title of corporate social responsibility as an instrument for the purpose of creating a positive mental image of the brand regarding Mellat Bank. The suitable mental image which was studied as a factor to increase the environmental dependencies powers in the present research.

The results of this research regarding the fact that the main hypothesis was accepted on the basis of the relationship between corporate social accountability and seeking to create a position for the special value of the brand from the standpoint of gaining more power in the competitive market, could be regarded as being in line with "Amirshahi \& Abbasiyan's" (2005) research which studied the effect of the perception from the brand regarding social identity and status on the reaction of the consumers including: accepting the generalization of the brand, suggesting it to others and paying more money for it about brands in industry, and evaluated it as significant.

- Taking into account the fact that corporate social accountability had no significant effect on the increase in the desirability of the environmental dependencies of the special value of the brand of the company from the viewpoint of the clients of Melli and MEllat Banks, the results of this research regarding the relationship between corporate social responsibility and the desirability of the brand of the company are in contrast with the results of Lajevardi and Rahchamani's (2012) research results which states that the type of the plan of corporate social responsibility and the perceived quality of the brand have a significant effect on the clients' preference, in this research quality was in line with the level of resulted satisfaction from consuming the products and services or the sweated services which are in line with the definition of desirability.

Taking into account the results of the research which show that corporate social accountability had no significant impact on the increase of the level of uniqueness of the environmental dependencies of the special value of the brand form the viewpoint of the clients of Melli and Mellat, the results of the present research are in contrast with the results of Kaur \& Agrawal's (2011) research which has considered corporate social accountability as an instrument to create distinguishability of the brand in comparison to other brands in the market .

The results indicate that the moderator variable of perceived coordination between the brand and the purpose of the company was of no effect in the relationship between corporate social accountability and the improvement of the special value of the brand from the viewpoint of the clients of Melli and Mellat Banks. It was only in the case of uniqueness where the perceived coordination between the brand and the company's purpose that it moderated the relationship between corporate social accountability and uniqueness from the viewpoint of the clients.

- The results also indicated that the moderator variable of the perceived coordination between the brand and the purpose of the company was not effective on the relationship between corporate social accountability and the increase in the power of environmental dependencies from the viewpoint of the clients of Melli and Mellat Banks. The results of the research in this section are in contrast with the researches of Lajevardi and Rahchamani (2012) which state that the type of corporate social responsibility plan and the perceived quality have a significant impact on the preference of the clients. In this research quality is defined as the level of the resulted satisfaction from consuming products and or sweated services which are equal to the definition of desirability.

- On the other hand the results indicate that the moderator variable of the perceived authenticity from the company's claim (in the existence statement of the company) had no effect on the relationship between corporate social accountability and the improvement of the special value of the brand from the viewpoint of clients of Melli and Mellat Banks. It was only in the case of the power variable from the viewpoint of Mellat Bank's clients that the perceived authenticity and the purpose of the company that it moderated the relationship between the corporate social accountability and power from the viewpoint of the clients.

- The results regarding the seventh hypothesis indicated the moderator effects of the moderator variable of perceived authenticity from the company's claim (existence statement of the company) on the relationship between corporate social accountability and the increase in the power of environmental dependencies of the special value of the brand from the viewpoint of the clients of Melli Bank while the perceived authenticity between the brand and the purpose of the company moderates the relationship between corporate social accountability and the increase in the environmental dependencies of the brand from the viewpoint of the clients of Mellat Bank as a private bank. 


\section{Suggestions and Implications}

As it is clear from their definition, brands are the primary and most obvious proof of a company. But in Iran the void of international brands is still felt. May be the cause for paying less attention to brands could be searched in the existence of inflationary economy in Iran which causes an increase in the value of fixed assets of economic agencies (even the ones undergoing loss) and the fact that the managers do not tend to invest in unobservable assets such as brands. May be the cause for it is in the lack of the view of finance- axis in comparison to brands in the eyes of the Iranian managers and that they consider gaining income from brands as impossible which undoubtedly has its roots in the existence of the view of managing expenses (cutting back on specializing) rather than a view of income management in the country.

But what seems to be of importance is the importance of the evaluation the client does from a successful brand. Today's industrial societies, are preoccupied with attracting clients and customers and something beyond the material and spiritual expectations of the client from making a connection with a specific brand causes an ever growing attention to a new concept titled corporates' social accountability for all people who benefit from it in the society in which they operate in.

This concept is a dynamic one and our country is located at the start of it.

Taking into account the present research's results and the fact that three major hypotheses of the research regarding Melli Bank as a governmental bank were rejected and two of the major hypotheses were rejected and the first hypothesis was accepted about Mellat bank as a private bank, and the spins it had between the existence of significant relationships between the variables of the research were mostly in favor of Mellat Bank as a private bank and it was even proven that the role of the moderator of the perceived authenticity from the company's claim was effective on the relationship between corporate social accountability and the increase in the power of environmental dependencies of the company as an aspect of the special value of the brand of the company, the following suggestions in line with developing and generalizing accountability position and increase of the value of the brand of the company will be presented in general:

- Taking into account the fact that most of the society's managers have not enough and essential awareness of social responsibility and its aspects, it is necessary to familiarize the managers of different sections of the society with social responsibilities through holding conferences, seminars, short- term educational courses and different lectures. In the above- mentioned trainings we should try to make an effort to make the managers aware of social responsibility and its aspects, the strategies for carrying out social responsibilities and its positive effects in the organization and in line with promoting the economic aspect of their social accountability they must commit themselves to providing the most benefits for their clients and shareholders.

Regarding the legal aspect of social accountability they must try to follow the banking and internal finances and international regulations and instructions while being bound to all their professional commitments and they must obligate themselves to answer honestly, straight and with respect to supervision institutions.

In the ethical aspect of social accountability they should be committed to confidentiality and the safeness of the clients' information and regard it as a principle.

Regarding the other responsibilities (voluntary) in social accountability, they must regard aiding educational and cultural institutes or welfare aids to the charity institutes in line with their authority clearly as their social commitments.

In Branding Area:

The necessity to attend to brands, identifying the opportunities in the related industry and making an effort to promote the position of the brand of a company in the mind of the beneficiaries of the company, gaining competitive benefits which lead to a company being unique in the related industry, which all lead to progress in the company's making more profit, are the most fundamental measures in the area of branding.

- In this respect this major belief must be created that managing the brand has an essential role in the success and the company's operations being effective and this must be done through holding meetings and special seminars especially for the managers.

- The managers of industries must also regard the payable expenses for seeking to create a position and promoting the aspects of the brand of the company as the expenses of the company and should consider it as an asset of the company.

The last era and to some extend the current era is the era of flourishing and entrepreneurship the upcoming era and the current period are the era of new ideas and creating brands. In this era it is the brands which determine the development or failure of business.

\section{Research limitations and delimitations}

Amongst the limitations which were not controlled in the present research the followings could be pointed out: 
1. Although the researcher has tried to as much as possible use the questionnaires which were in accordance with the presented models through the theorists of the concepts of the research and also in accordance with the banking industry's atmosphere, taking into account the fact that all the data was in the form of survey from the clients about their perceptions from corporate social accountability and their mental image of the brand in the understudy banks therefore the common method of bias is also a noticeable issue.

2. Also with regard to gathering the data about the special value of the brand on the basis of the clients the researcher's efforts for the individuals who were commonly clients of Melli Bank or Mellat Bank to complete the questionnaires, and explaining to them that they should complete the questionnaire with the view that they are the clients of only that specific bank we should not forget that in the recent years the amount of the transfers people do and the times they need to go to various banks have increased and also the number of financial institutes and banks have increased and there is the possibility that most of the people who answered the questions were simultaneously the clients of both governmental and private banks and have considered the special value of the brand in the whole banking industry when answering the questionnaires.

\section{Recourses}

[1]. Aaker, D. A. (1992) . "TheValue of Brand Equity", The Journal of Business Strategy, 13 (4), 27-32.( in Persian)

[2]. Allahyari, Ashkan (2009), Improving the special value of a brand on the basis of the clients through creating a mentality of functional and nonfunctional benefits, management outlook, number 30, p.p. 29-48.( in Persian)

[3]. Amirshahi, Mirahmad and Abbasiyan, Farzaneh (2007) "Studying the effect of the perceptions of the consumers of the brands on their reactions", Humanistic and social sciences management journal, seventh year, number 25.( in Persian)

[4]. Azar, Adel and Momeni, Mansoor (2008), statistics and its applications in management, volume 2, Tehran Samt publications.( in Persian)

[5]. Benoit- Moreau , Florence(2011)," Building brand equity with environmental communication: an empirical investigation in France",EuroMed Journal of Business,Vol. 6 No. 1, pp. 100-116

[6]. Crane, Andrew, Mutton, Derek, and J. Spenser, Laura (2009) “organizations' social responsibility” translated by Majid Seraydariyan, Mohammad Hasan Emami and Alireza Jabbari, Isfahan Aseman negar second edition .( in Persian)

[7]. Galbreath, Jeremy, (2010),"How do corporate social responsibility benefit firms?" European Business Review, Vol.22No.4, P412417

[8]. Ghalandari, Kamal and colleagues (2010) "studying the aspects of the social power of brand on the basis of mental readiness levels of the clients on deciding to purchase" management researches magazine, number 86.( in Persian)

[9]. Kaur, Maneet\& Agrawal, Sudhir,(2011)," CORPORATE SOCIAL RESPONSIBILITY - A TOOL TO CREATE A POSITIVE BRAND IMAGE", ASBBS Annual Conference: Las Vegas 681 February 2011.

[10]. Khaki, Gholamreza (2008), "research method with an approach to writing a thesis" Baztab Publications, fifth addition .( in Persian)

[11]. Lajevardi, Lida and Rahchamani, Ahmad (2012) "studying the effects of the measures of corporate social responsibility (CSR) on brand preference in banking industry (case study Mellat and Refah Banks, marketing articles periodical, first edition.

[12]. Janonis, V.; Dovaliene, A. and Virvilaite, R. (2007),"Relationship of Brand Identity and Image", Engineering Economics , 1, 69-79 